Pacific Northwest

National Laboratory

Operated by Battelle for the

US Department of Energy

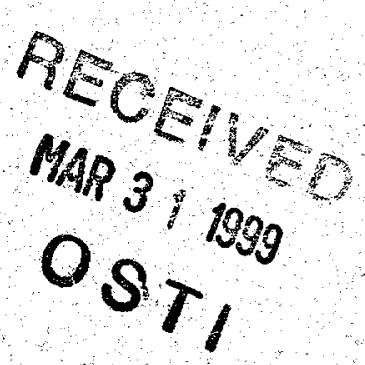

\title{
Borehole Data Package for 216-U-12 Crib Well 299-W22-79
}

D. G. Horton

B. A. Williams

March 1999

Prepared for the U.S. Department of Energy under Contract DE-AC06-76RLO 1830 


\title{
DISCLAIMER
}

This report was prepared as an account of work sponsored by an agency of the United States Government. Reference herein to any specific commercial product, process, or service by trade name, trademark, manufacturer, or otherwise does not necessarily constitute or imply its endorsement, recommendation, or favoring by the United States Government or any agency thereof, or Battelle Memorial Institute.

\author{
PACIFIC NORTHWEST NATIONAL LABORATORY \\ operated by \\ BATTELLE \\ for the \\ UNITED STATES DEPARTMENT OF ENERGY \\ under Contract DE-AC06-76RLO 1830
}

Printed in the United States of America

\author{
Available to DOE and DOE contractors from the \\ Office of Scientific and Technical Information, P.O. Box 62, Oak Ridge, TN 37831; \\ prices available from (615) $576-8401$. \\ Available to the public from the National Technical Information Service, \\ U.S. Department of Commerce, 5285 Port Royal Rd,, Springfield, VA 22161
}




\section{DISCLAIMER}

This report was prepared as an account of work sponsored by an agency of the United States Government. Neither the United States Government nor any agency thereof, nor any of their employees, make any warranty, express or implied, or assumes any legal liability or responsibility for the accuracy, completeness, or usefulness of any information, apparatus, product, or process disciosed, or represents that its use would not infringe privately owned rights. Reference herein to any specific commercial product, process, or service by trade name, trademark, manufacturer, or otherwise does not necessarily constitute or imply its endorsement, recommendation, or favoring by the United States Government or any agency thereof. The views and opinions of authors expressed herein do not necessarily state or reflect those of the United States Government or any agency thereof. 


\section{DISCLAIMER}

Portions of this document may be illegible in electronic image products. Images are produced from the best available original document. 


\section{Borehole Data Package for 216-U-12 Crib Well 299-W22-79}

D. G. Horton

B. A. Williams

March 1999

Prepared for

the U.S. Department of Energy

under Contract DE-AC06-76RLO 1830

Pacific Northwest National Laboratory

Richland, Washington 99352 


\section{Contents}

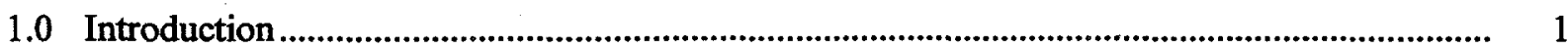

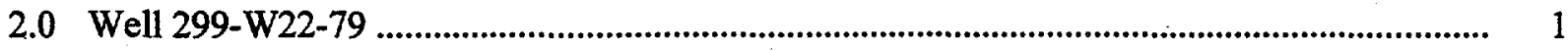

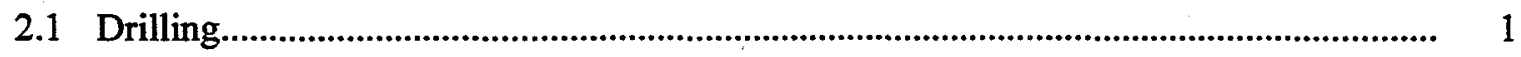

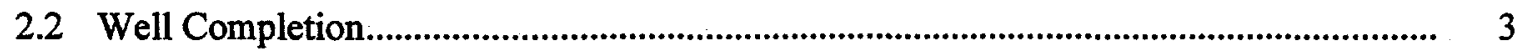

2.3 Well Development and Pump Installation ................................................................... 3

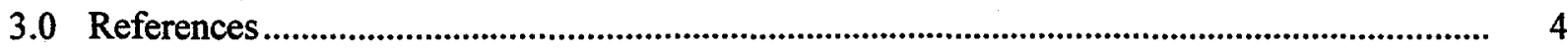

Appendix - Well Construction and Completion Documentation .................................................. 7

\section{Figure}

1 Locations of Wells in the Groundwater Monitoring Network at the 216-U-12 Crib

\section{Table}

1 Survey Data for Well 299-W22-79. 


\subsection{Introduction}

One new Resource Conservation and Recovery Act (RCRA) groundwater monitoring well was installed at the 216-U-12 crib in September 1998 in support of Tri-Party Agreement (Ecology 1996) milestone M-24-36. The new well is $299-\mathrm{W} 22-79$ and is a downgradient well in the groundwater monitoring network. There are a total of six wells in the groundwater monitoring network for the $216-U-12$ crib and their locations are shown on Figure 1.

The groundwater assessment monitoring plan for the 216-U-12 crib (Chou and Williams 1993) describes the hydrogeology of the 200 West Area and the 216-U-12 crib area. An Interim Change Notice to the assessment plan provides justification for the well (Chou and Williams 1997). The new well was constructed to the specifications and requirements described in Washington Administrative Code (WAC) 173-160, and WAC-173-303, and in Chou and Williams (1997).

This document compiles information on the drilling and construction, well development, and permanent pump installation applicable to well 299-W22-79. Appendix A contains the geologist's log, the Well Construction Summary Report, and Well Summary Sheet (as-built diagram). Additional documentation concerning well construction is on file with Bechtel Hanford, Inc., Richland, Washington.

English units are used in this report because they are used by drillers to measure and report depths and well construction details. The conversion is made by multiplying feet by 0.3048 to obtain meters; or multiplying inches by 2.54 to obtain centimeters.

\subsection{Well 299-W22-79}

\subsection{Drilling}

Well 299-W22-79 was drilled using an air rotary rig in September 1998. The well was completed at a total depth of $286 \mathrm{ft}$ below ground surface (bgs). Temporary $85 / 8 \mathrm{in}$.-outside-diameter, carbon steel casing was used during drilling from surface to total depth. No water was added to the well during drilling. Static water level was $241 \mathrm{ft}$ bgs on September 30, 1998.

Sediments encountered during drilling were predominantly Hanford formation sand and silty sand from the surface to about $156 \mathrm{ft}$ bgs; Plio-Pliestocene silt and sandy silt between 156 and $236 \mathrm{ft}$ bgs; and Ringold Formation Unit E sandy gravel and gravelly sand between $236 \mathrm{ft}$ and the bottom of the well (286 ft bgs). The geologists' log is included in Appendix A. Sediment samples were collected for geologic description and archival at approximately $10 \mathrm{ft}$ intervals throughout the entire well. In addition, five grab samples of sediment were collected between 232 and $242 \mathrm{ft}$ bgs for analysis of residual contamination remaining on sediment surfaces from a declining water table; no analyses have been done on these samples to date. 


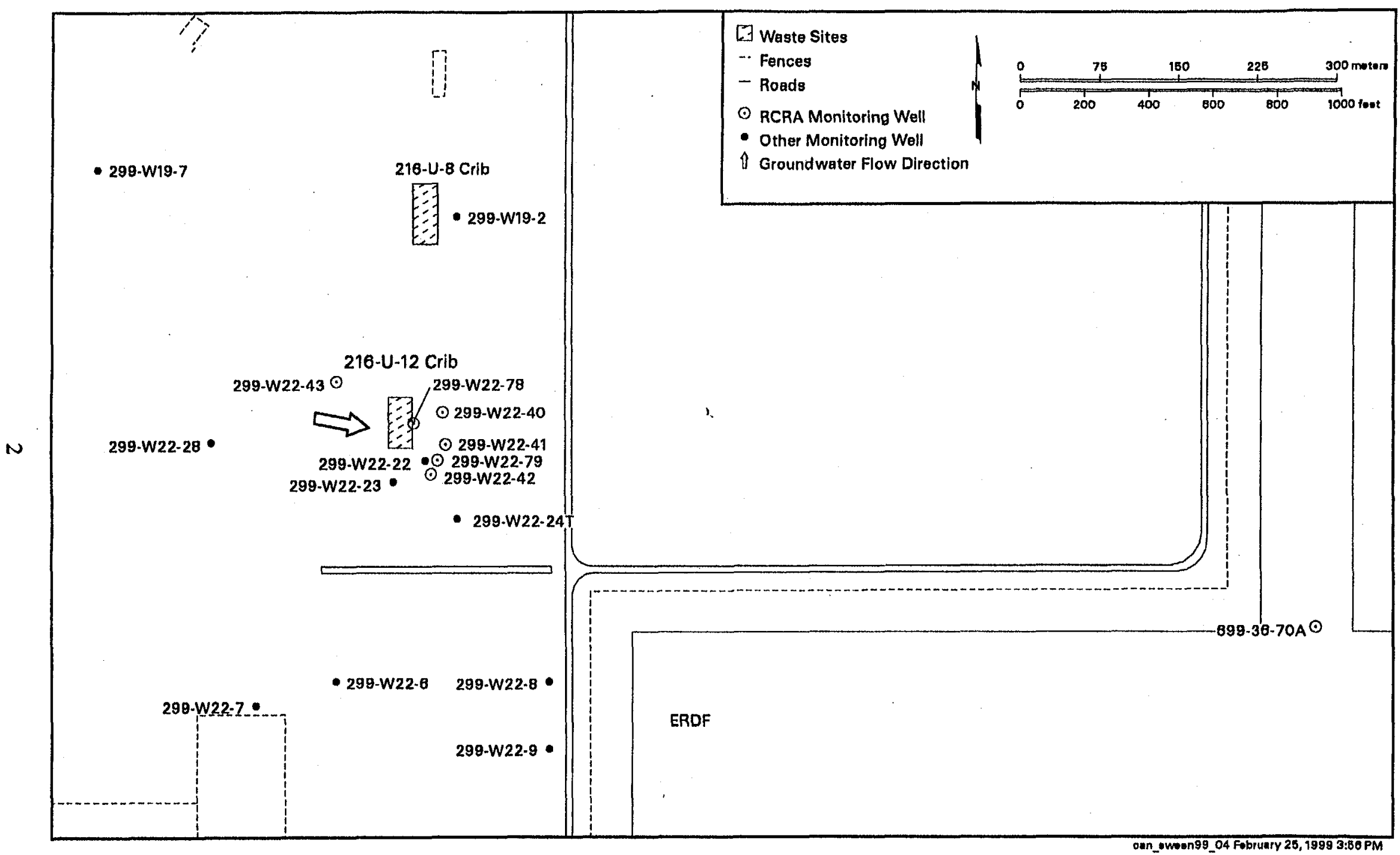

Figure 1. Locations of Wells in the Groundwater Monitoring Network at the 216-U-12 Crib 
The borehole and drill cuttings were monitored regularly for organic vapors and radionuclide contaminants. One hundred counts per minute were measured on cuttings from about $230 \mathrm{ft}$ bgs (below PlioPliestocene fine grained sequence) where the radiation control technologist put a temporary hold on drilling. A 2 L sample (sample number BOR1L8) was collected for analysis at this depth. The radiation detected was radon.

\subsection{Well Completion}

The permanent casing and screen were installed in well 299-W22-79 in September 1998. A 4-in.diameter, stainless steel, continuous wire wrap ( 0.01 in. slot) screen was set from 242.7 to $277.8 \mathrm{ft}$ bgs. The permanent casing is 4-in.-inner-diameter, stainless steel from $242.7 \mathrm{ft} \mathrm{bgs}$ to $2 \mathrm{ft}$ above ground surface. Centralizers were placed above and below the screen and every $40 \mathrm{ft}$ from the screen to ground surface. The bottom of the screen has a 4 in. end cap.

The filter pack is 20 to 40 mesh silica sand from 282.6 to $230.4 \mathrm{ft}$ bgs; the annular seal is 0.25 to 0.38 in. dry bentonite chunks between 230.4 and $11.1 \mathrm{ft}$ bgs. The remaining annulus $(11.1 \mathrm{ft}$ bgs to ground surface) was filled with Portland cement. An 8-in.-diameter carbon steel protective casing, with a locking cap, was set from $3 \mathrm{ft}$ bgs to $3 \mathrm{ft}$ above ground surface. A $4 \mathrm{ft}$ by $4 \mathrm{ft}$ by 6 in. concrete pad was placed around the well at the surface with 4 protective steel posts set into the concrete. A brass marker stamped with the well number was placed into the concrete. The Well Construction Summary Report and the Well Summary Sheet are included in Appendix A.

The vertical and horizontal coordinates of the well were surveyed in December 1998. The horizontal position of the well was determined by global positioning system observations referenced to horizontal control stations established by the U.S. Army Corps of Engineers. The coordinates are Washington Coordinate System, South Zone, NAD83/91 datum. Vertical datum is NAVD 1988 and is based on existing bench marks established by the U.S. Army Corps of Engineers. Survey data are included in Table 1.

Table 1. Survey Data for Well 299-W22-79

\begin{tabular}{|c|c|c|c|l|}
\hline Well Name & Easting $(\mathrm{m})$ & Northing $(\mathrm{m})$ & Elevation $(\mathrm{m})$ & \\
\hline $299-\mathrm{W} 22-79$ & $567,629.5395$ & $134,464.8455$ & & Center of Casing \\
& & & 211.7349 & "X" on Casing \\
& $567,629.5265$ & $134,465.168$ & 210.9408 & Brass Cap \\
\hline
\end{tabular}

\subsection{Well Development and Pump Installation}

Well 299-W22-79 was developed on October 29, 1998. A temporary, 2 hp submersible pump was used to remove approximately $2,500 \mathrm{gal}$ of formation water from the well at about $7 \mathrm{gal} / \mathrm{min}$. The final turbidity was 12 NTU. 
A dedicated Hydrostar sampling pump was installed in well 299-W22-79 on October 30, 1998. The sampling pump intake is at $261.50 \mathrm{ft}$ depth relative to the brass cap (see Table 1) or approximately $20 \mathrm{ft}$ below the water table.

\subsection{References}

Chou, C. J., and B. A. Williams. 1993. Interim-Status Groundwater Quality Assessment Plan for the 216-U-12 Crib. WHC-SC-EN-AP-108, Westinghouse Hanford Company, Richland, Washington.

Chou, C. J., and B. A. Williams. 1997. Interim Change Notice to Interim-Status Groundwater Quality Assessment Plan for the 216-U-12 Crib. ICN-WHC-SD-EN-AP-108.1R0, Westinghouse Hanford Company, Richland, Washington.

Ecology - Washington State Department of Ecology, U.S. Environmental Protection Agency, and U.S. Department of Energy. 1996. Hanford Federal Facility Agreement and Consent Order. Document No. 89-10, Rev. 4 (The Tri-Party Agreement), Ecology, Olympia, Washington.

RCRA - Resource Conservation and Recovery Act. 1976. Public Law 94-580, as amended, 90 Stat. 2795, 42 USC 6901 et seq.

WAC 173-160, Washington Administrative Code. Minimum Standards for Construction and Maintenance of Wells. Olympia, Washington.

WAC 173-303, Washington Administrative Code. Dangerous Waste Regulations. Olympia, Washington. 
Appendix

Well Construction and Completion Documentation 


\section{WELL CONSTFUCTION SUMMARY REPOR ।}

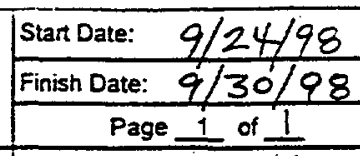

\begin{tabular}{|l|}
\hline Specification No.: $01006-$ SWE: Rev. No.: 1 \\
\hline ECNs: NA \\
\hline Project 1998 RCRA Drilling \\
\hline Driling Company: Layne Christensen \\
\hline Driller. W. Fran Elin \\
\hline TEMPORARY CASING AND DRILL DEPTH \\
\hline
\end{tabular}

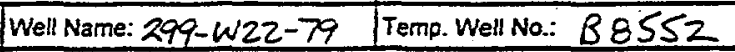
Approximate Location: 14 mile South of U-Plant, $200 \mathrm{~W}$ Other Companies: $\mathrm{CH} 2 \mathrm{M} \mathrm{Hill}$ Geologist(s):

\begin{tabular}{|c|c|c|}
\hline Size/Grade/Lbs. Per Ft & interval & Shoo 0.D J.D. \\
\hline Carbon steel (FJ) & $0 .-285^{\prime}$ & $85 / 8 \% / 8^{\circ}$ \\
\hline & - & \\
\hline & - & \\
\hline & - & \\
\hline & - & \\
\hline
\end{tabular}

Indicate Welded (W) - Flush Joint (FJ) Coupled (C) \& Thread Design

\begin{tabular}{|c|c|c|}
\hline Auger. & Diameter From & to \\
\hline Cable Tool: & Diameter From. & to \\
\hline Air Rotary: 70 bex $\left(9^{\prime \prime}\right)$ & Diameter From $0^{\prime}$ & to $286^{\prime}$ \\
\hline A.R. w/Sonic: & Diameter From & to \\
\hline & Diameter From & to \\
\hline & Diameter From & to \\
\hline & Diameter From _ & to \\
\hline
\end{tabular}

\begin{tabular}{|l|l|l|}
\hline Total Dilled Depth: $286^{\prime}$ & Hoie Dia @ TD: $9^{\prime \prime}$ \\
\hline Well Straightness Test Results: NA & \\
\hline
\end{tabular}

Total Amt. Of Water Added During Dilling: . None Static Water Level: 241.91 Date: $9 / 30 / 98$

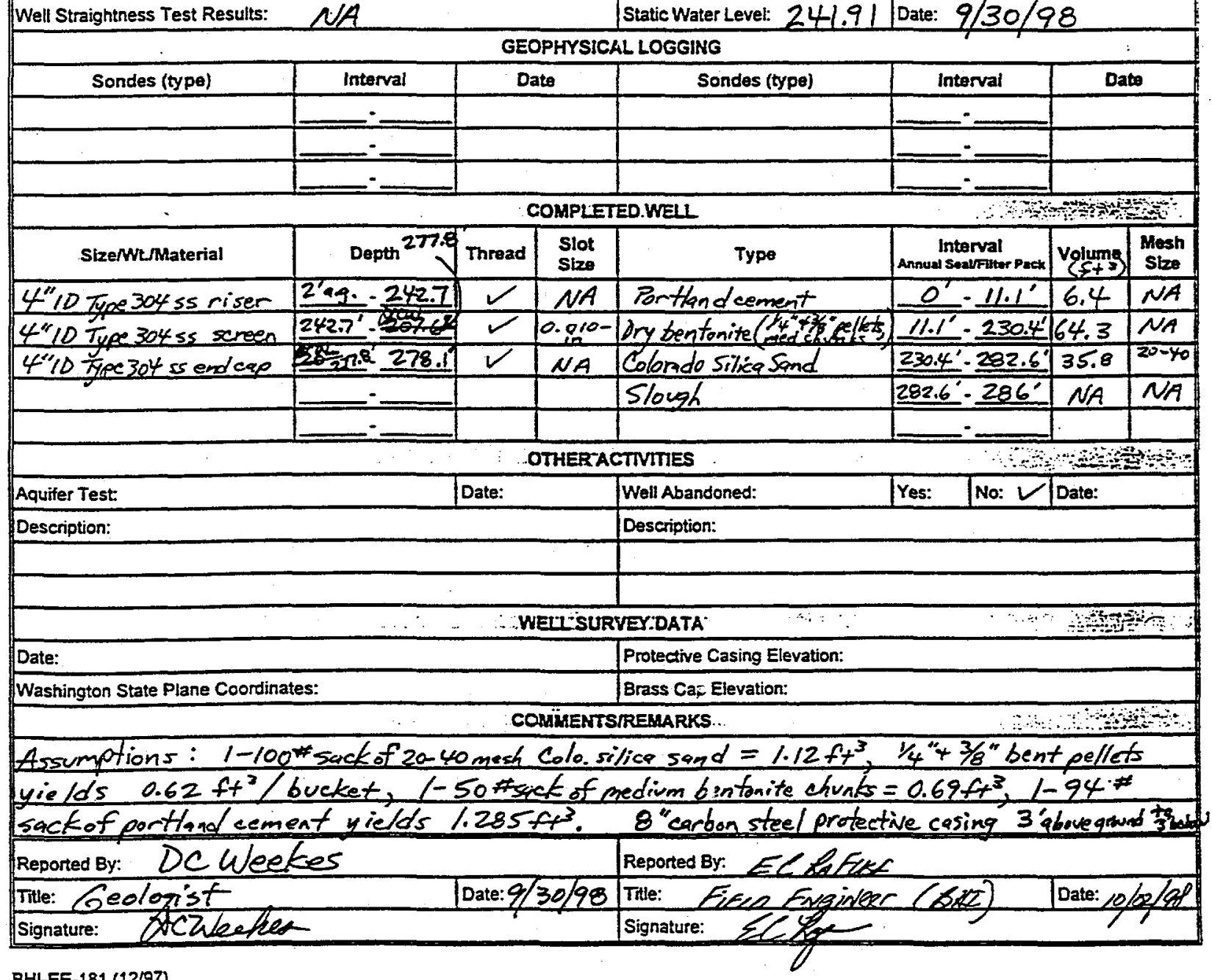

BHI-EE-181 (12/97) 


\begin{tabular}{|c|c|c|c|c|}
\hline \multicolumn{5}{|c|}{ WELL SUMMARY SHEET } \\
\hline ell ID: $B 8552$ & $\cdot$ & \multicolumn{3}{|c|}{ |Well Name: $299-$ W $22-79$} \\
\hline \multicolumn{2}{|c|}{ Location: $1 / 4$ mi South of U-Plant, Zoow } & \multicolumn{3}{|c|}{ Project: 1998 RCRA Drilling } \\
\hline Prepared By: DC Weekes & Date: $9 / 29 / 98$ & \multirow{2}{*}{\multicolumn{3}{|c|}{ 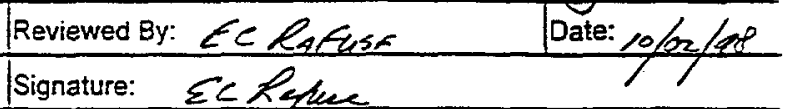 }} \\
\hline \multirow{2}{*}{\multicolumn{2}{|c|}{ Signature: DC Ulee het }} & & & \\
\hline & \multirow[b]{2}{*}{ Diagram } & \multicolumn{3}{|c|}{ Signature: $\quad \sum E$ Regee } \\
\hline Description & & $\begin{array}{c}\text { Depth in } \\
\text { Feet }\end{array}$ & $\begin{array}{c}\text { Graphic } \\
\text { Log }\end{array}$ & Lithologic Description \\
\hline $8^{11}$ carbon steel protective & \multirow{5}{*}{ 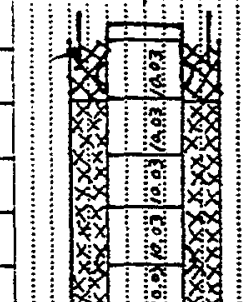 } & \multirow[t]{4}{*}{ o- } & \multirow{3}{*}{ o } & \\
\hline casing 3 'ag. to $3^{\prime}$ bgs. & & & & $0^{\prime}-12^{\prime}:$ Silty SAND \\
\hline & & & & 12-34: Gravelly SAND \\
\hline & & & & $34^{\prime}-94^{\prime}:$ SAND \\
\hline 4"ID Type 304 stainless steed & & & & \\
\hline riser:2'a.g. $-242.7^{\prime}$ & 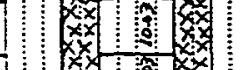 & & & \\
\hline 4"ID Type 304 stainless steel & (ix & & & \\
\hline continuous wire wrap sereen & 10 & & 6 & thin layers of sitty sand $76^{\circ} 78^{\circ}$ \\
\hline$(0.010-$ in slof $): 242 .-277.8$ & 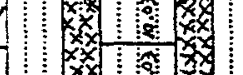 & & 4 & thin layers of silty sande $85^{\circ}+88^{\circ}$ \\
\hline Bottand cement $0^{\prime}-11.1^{\prime}$ & 絃 & & & $98^{\prime}-104^{\prime}:$ SAND \\
\hline Dru bentonite (" " $73 / 8$ "pellets) & In & & & $104^{\prime}-125^{\prime}:$ Sitty SAND \\
\hline and medium chunks): $\left(1.1^{\prime \prime}-230.4^{\prime}\right.$ & 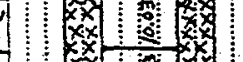 & & & $125^{\prime}-128^{\prime}:$ SAND \\
\hline & & & & $128^{\prime}-132^{\prime}:$ Silty SAND \\
\hline Colorado Silica Sand (20-40 med): & {$\left[\begin{array}{l}0 \\
x \\
x \times x\end{array}\right]$} & 150 & 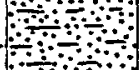 & $132^{\prime}-138^{\prime}:$ SAND \\
\hline $230.4^{\prime}-282.6^{\prime}$ & {$\left[\begin{array}{ll}x \\
x \\
x\end{array}\right]$} & & & $138^{\prime}-156^{\prime}:$ Silty SAND \\
\hline Slough $282.6^{\prime}-286.0^{\prime}$ & 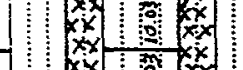 & & 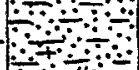 & $156^{\prime}-161^{\prime}:$ SiLT \\
\hline & 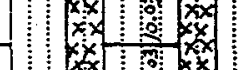 & & & $161^{\prime}-187^{\prime}:$ Sandy SILT \\
\hline Centralizers above and below & $\left(\begin{array}{l}x \\
x \\
x \\
x \\
x \rightarrow y\end{array}\right.$ & & 80 & $187^{\prime}-194^{\prime}$ : Silty Sendy GRAVEL \\
\hline the screen and every $40 \mathrm{ft}$ & 集 & & & $194^{\prime}-226^{\prime}:$ Sandy SILT \\
\hline and as indicated & 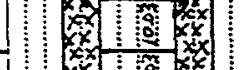 & & 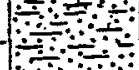 & \\
\hline & 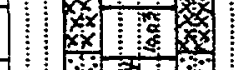 & & & $226^{\prime}-236^{\prime}:$ SAND \\
\hline & 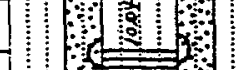 & & $\%$ & $236^{\prime}-28^{\prime}: 54$ istlysity Gravely SAND \\
\hline Water level $(9 / 30 / 98): 241.91^{\prime}$ & $F=$ & 25 & 0 & $238-245: G$ mavelly SAND \\
\hline & 1 & & & $245^{\circ}-270^{\circ}:$ Sandy GRAVEL \\
\hline All temporary casingremoved. & +8 & & 0 & \\
\hline Allder & $\frac{1}{\sin a x}$ & & & TDe 286'9/26/98 \\
\hline
\end{tabular}

BHI-EE-189 (12/97) 


\section{BOREHOLE LOG}

Baring or Wall No. $299-W 22-79 / B 8552$.

Sheat $\frac{1}{4}$ of 4

Locetion $200 \mathrm{~W} ;-1 / 4$ mile south of 4 Plant Projoet RCRA Drilling 1998

Propsred By phle le /L.D. Walker Date 9-24-98

Roviowed BY

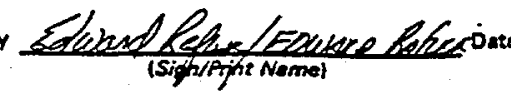

$\frac{10 \operatorname{lo} 2 \log }{1}$

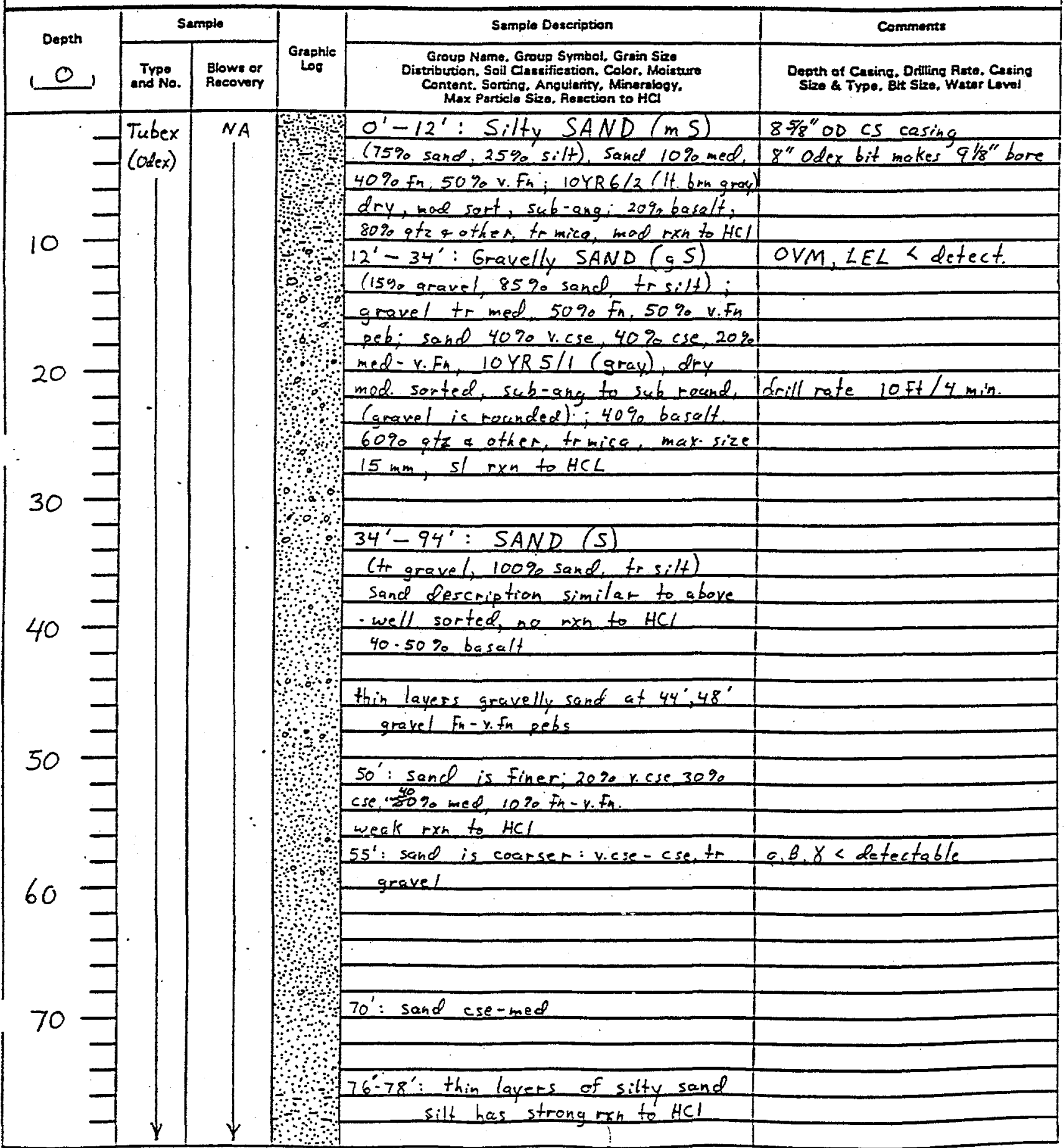




strent 2 of 4

Location $200 \mathrm{~W}, \approx 1 / 4$ mile south of u plaint project RCRA Drilling 1998

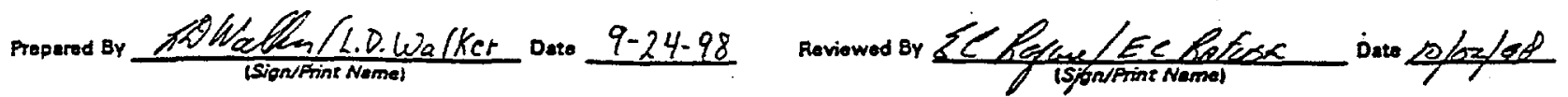

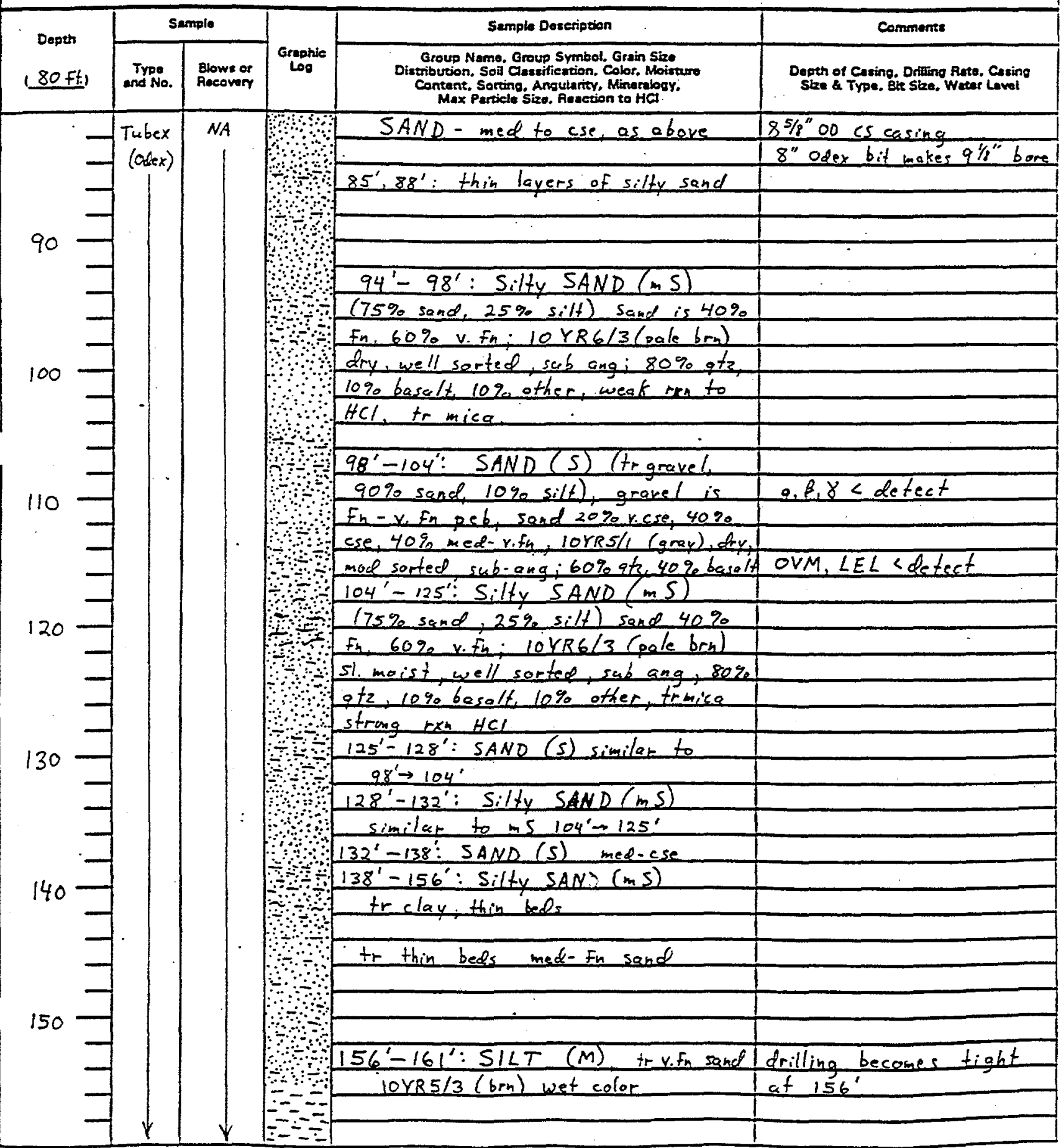




\section{BOREHOLE LOG}

Boring or Well No. 299-W22-79/B8552

sheet 3 ot 4

$$
\begin{aligned}
& \text { Loeation } 200 \mathrm{~W}: 21 / 4 \text { mile south of u Ploint Project RCRA Drilling } 1998
\end{aligned}
$$

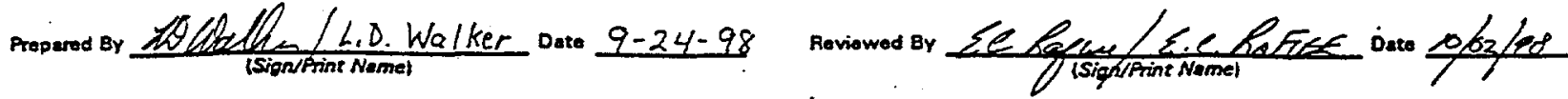

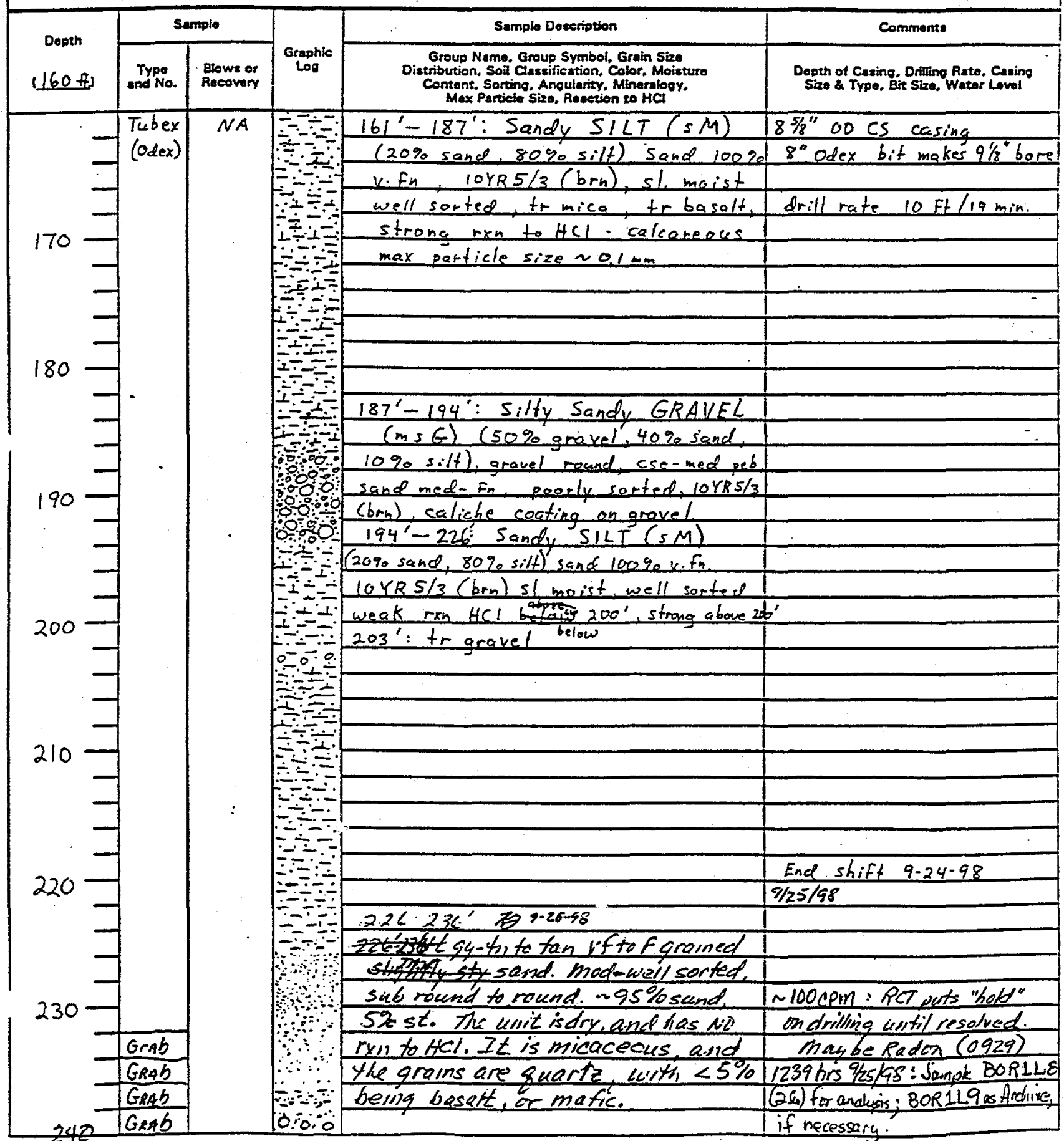


Loention 1/4mi south ofleplewnt, joowest projoct RCRA Drilling 1998

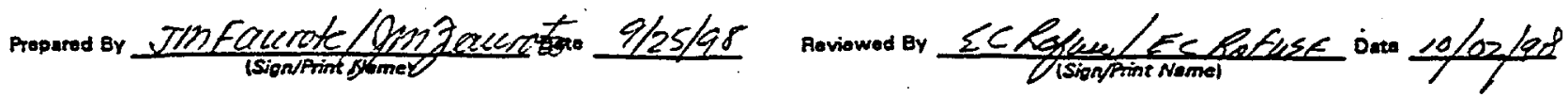

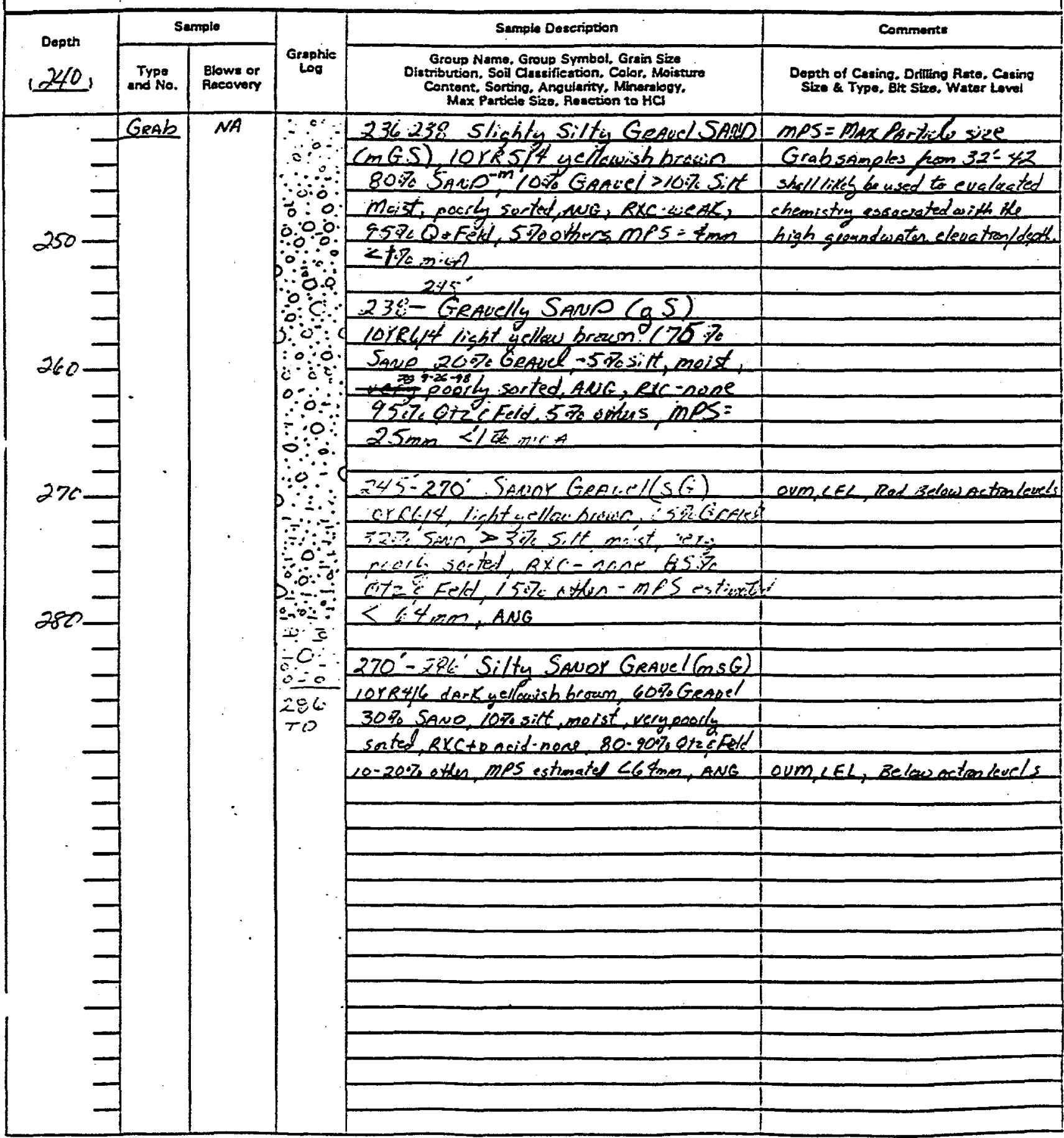




\section{Distribution}

No. of

Copies

\section{OFFSITE}

J. Donnally

Washington State Department of Ecology

1315 4th Avenue

Kennewick, WA 99336

\section{ONSITE}

2 DOE, Richland Operations Office

M. J. Furman

H0-12
No. of

Copies

2 Bechtel Hanford Company
J. V. Borghese
H0-19
A. J. Knepp
H0-19

19 Pacific Northwest National Laboratory
G. R. Holdren
K6-81
D. G. Horton (3)
K6-81
S. P. Luttrell
K6-96
L. F. Morasch
K6-86
F. A. Spane, Jr.
K6-96
B. A. Williams (5)
K6-81
Information Release Office (7)

Distr.1 